\title{
POSSIBILITIES OF DETERMINING THE AIR-PORE CONTENT IN CEMENT COMPOSITES USING COMPUTED TOMOGRAPHY AND OTHER METHODS
}

\author{
MOŽNOSTI DOLOČANJA VSEBNOSTI ZRAČNIH POR V \\ CEMENTNIH KOMPOZITIH Z UPORABO RAČUNALNIŠKE \\ TOMOGRAFIJE IN DRUGIH METOD
}

\author{
Bronislava Moravcová, Petr Pőssl, Petr Misák, Michal Blažek \\ Brno University of Technology, Faculty of Civil Engineering, Veveří 331/95, 60200 Brno, Czech Republic \\ BlazekM7@study.fce.vutbr.cz \\ Prejem rokopisa - received: 2014-08-13; sprejem za objavo - accepted for publication: 2015-08-24
}

doi:10.17222/mit.2014.193

\begin{abstract}
The aim of the paper is to outline the possibilities and predictive values of the selected methods for determining air-pore characteristics in concrete and cement composites in general. Four samples (mixtures) of cement concrete without additives or admixtures were chosen for the measurement, differing in cement content while maintaining the consistency of fresh concrete S3 according to EN 206. Both standardized and non-standardized methods are used in Europe, therefore providing a possibility of comparing their outcomes.

Keywords: concrete, durability, porosity, surface, covering layer, X-ray computed micro-tomography
\end{abstract}

Namen članka je prikazati možnosti za splošno napovedovanje izbranih metod za določanje značilnosti zračnih por v betonu in v kompozitih iz cementa. Za meritve so bili izbrani stirje vzorci (mešanice) betona brez dodatkov in primesi z različno vsebnostjo cementa ob zadržanju konsistence svežega betona S3, skladno z EN 206. Standardizirane in nestandardizirane metode se uporabljajo v Evropi in zato omogočajo primerjavo rezultatov.

Ključne besede: beton, zdržljivost, poroznost, površina, prekritje, rentgenska računalniška mikro-tomografija

\section{INTRODUCTION}

The durability of cement composites has been a topic of increasing importance. It is illustrated by the fact that the requirement for the durability of concrete structures has become part of CPR (Construction Products Regulation). ${ }^{1}$ The content, size and distribution of air pores, i.e., porosity, influence not only on the durability but also the physical/mechanical properties of cement composites and thus concrete structures in general. ${ }^{2}$

Recently, there have been claims that concrete air entrainment in percent is not sufficiently informative as both the air-entrained concrete and the traditional concrete contain a broad spectrum of air voids (Figure 1). Not all the pores are beneficial for the required property. Recent investigations argue that an effective entrainment (a pore diameter of $1 \mu \mathrm{m}-1000 \mu \mathrm{m}$ ) above $2 \%$ can significantly increase the resistance to water and chemical thawing agents. ${ }^{3-5}$

The pores can be divided, according to their characters $^{3}$, into gel, capillary, entrained and entrapped ones, or by their size ${ }^{4}$, into micropores $(<1.25 \mathrm{~nm})$, mesopores $(1.25-25 \mathrm{~nm})$, macropores $(25-5000 \mathrm{~nm})$ and other large pores $(5000-50000 \mathrm{~nm})$.

Figure 1 shows a detailed diagram of the division of pores and the possibilities of their detection by means of the methods discussed below.
In connection with what was mentioned above, four methods for determining various pore characteristics dealing with the air-void content in concrete (total air content, micropore air content, average pore diameter and specific surface of an air-void system) were chosen. Out of these, two are used for determining the properties of fresh concrete (the pressure method and the air-void analyser) and the remaining two for determining the properties of hardened concrete (a microscopic analysis and $\mathrm{CT}$ ).

The goal is to determine the air-pore-system characteristics using the above-mentioned methods and to

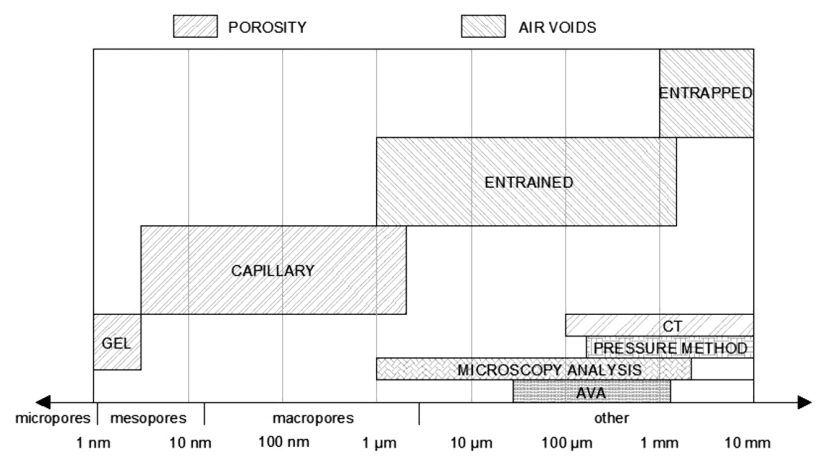

Figure 1: Example of pore size in concrete Slika 1: Primer velikosti por v betonu 
select the optimum method for determining the characteristics of specific types of the air-pore system in concrete.

\section{METHODS USED IN THE EXPERIMENT}

There is a number of situations where there is a need to have information about the pore distribution in concrete. This paper is concerned with the determination of concrete-cover porosity, which has a significant influence on the quality of the concrete and thus the durability of the whole structure. ${ }^{2}$ This experiment determines the concrete cover to be $40-60 \mathrm{~mm}$, taken from the surface of the specimen.

The following paragraphs describe standardised and non-standardised methods for the above-specified properties of fresh and hardened concrete, used in the experimental part of the research.

It must be emphasised that the results of the methods differ because of their different abilities to detect the pore size, due to the physical nature of the methods and differently sized specimens used for each method.

\subsection{Pressure method}

The method is applied for determining the air content in compacted fresh concrete made of dense or heavyweight aggregate. It is based on the Boyle-Mariotte law, which says that the product of the pressure and volume of a gas is constant. This method uses an air meter according to EN $12350-7^{5}$ (Figure 2).

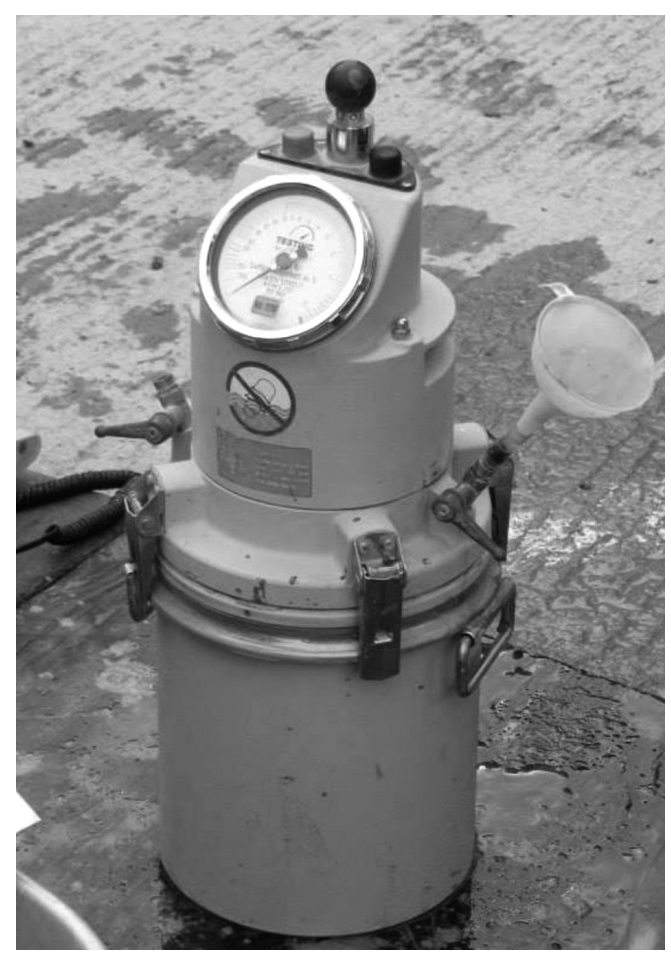

Figure 2: Concrete pressure-air meter Slika 2: Merilnik tlaka zraka v betonu

\subsection{Air-void analyser (AVA)}

For the analysis of the air-void structure in fresh concrete, AVA (an air-void analyser, Figure 3) was used., Its advantages are the possibility of taking samples directly from the vibrated mixture without any further processing and, as in the case of the previous method, the possibility of performing a measurement in situ. The apparatus also detects the content of microscopic air pores $A_{300}$, but it is necessary to note that it cannot detect pores smaller than $50 \mu \mathrm{m}$.

It was discovered that, under certain conditions, the air pores in a cement mixture can be transported into a liquid without affecting their content or size. ${ }^{8}$ Successful transport depends on the viscosity and hydrophilic character of the liquid. Once air bubbles have exited the cement paste, they start to rise through the liquid. The function of the air-bubble movement can be described with reversed Stokes' law, according to which larger bubbles rise faster than smaller ones. The total distribution of an air-void structure can be calculated by recording the amount of air that has risen up to a given level over the elapsed time. The number of pores escaping the cement paste is observed through the changes in the mass of an upside-down Petri dish placed just below the surface of the liquid.

The principle is that the apparatus determines the amount and size of air pores and thus enables an assessment of the spacing and the specific air-void surface. The method is primarily used for air-entrained concretes. However, even for non-entrained concretes, it is better at determining the air-void characteristics than method 2.1 as it can be used also for the determination of other characteristics, not just the total air content.

The following characteristics can be determined using this method:

- spacing factor,

- micro-air-void content $\left(A_{300}\right)$,

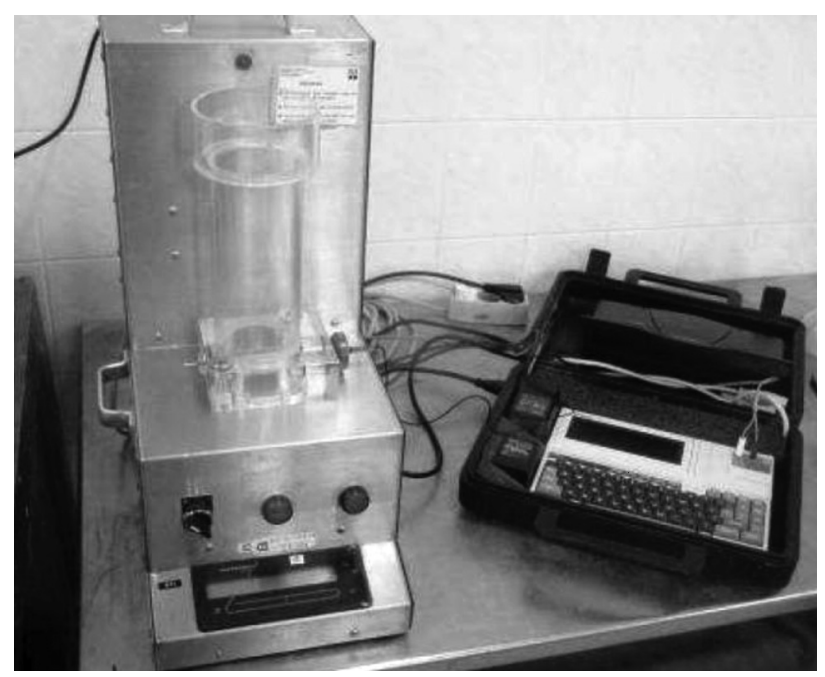

Figure 3 Air Void Analyzer (AVA)

Slika 3: Analizator praznin (AVA) 
- total air content,

- specific surface of an air-void system.

\subsection{Determining air-void characteristics in hardened concrete according to $\mathrm{EN}$ 480-11}

A stereoscopic microscope was used for the observation of the air-void diameter and distribution in hardened concrete according to the standard EN 480-11.9 This device detects pores of $1-4000 \mu \mathrm{m}$ and is able to identify microscopic air pores $\left(A_{300}\right)$. Prior to its use, the specimens need to be prepared from a concrete cured for a minimum of $7 \mathrm{~d}$. The measurement results can be recorded manually or automatically. Both procedures differ depending on human errors (the subjectivity of an evaluation) during pore detections (e.g., mistaking a hollow after a missing piece of the aggregate for an air pore).

The ability to detect air pores depends on the human ability to recognise a pore based on the contrast in the adapted specimen. During an automatic assessment, the factor is the resolution, at which a specimen is examined.

The following values can be determined using this method:

- spacing factor,

- micro-air-void content $\left(A_{300}\right)$,

- total air content,

- specific surface of an air-void system,

- average pore diameter.

\subsection{Computed tomography}

Computed tomography (CT) is a method, which enables us to look inside the specimens non-destructively. CT detects differences in the material density. A $3 \mathrm{D}$ visualisation of a specimen can be constructed through the processing of several consecutive slices. ${ }^{10}$

Using special SW, the following characteristics can be determined on a 3D image of a specimen:

- spacing factor,

- micro-air-void content $\left(A_{300}\right)$,

- total air content,

- specific surface of an air-void system,

- average pore diameter.

\section{EXPERIMENTAL PART}

The goal of this experiment was to compare the results of the selected methods used for the determination of air-pore characteristics in concrete and, at the same time, to ascertain whether the outputs of these methods correspond to one another. Four mixtures of cement concrete without additives or admixtures were chosen for the measurement, differing in the water/cement ratio while maintaining the consistency of fresh concrete S3 according to EN 206. ${ }^{11}$ The components of the concretes identified as $R(0 / 1,0 / 2$ and $0 / 3)$ are in Table 1 . The components in individual concretes were identical, i.e., of the same type of aggregate from the same location, one type of cement from the same mill.

The relevant properties of the concrete components were monitored according to EN 196-6 ${ }^{12}$, EN 933 ${ }^{13}$, and EN $1097^{14}$ (Table 2). Samples were taken according to EN 12350-1. ${ }^{15}$ Properties of fresh concrete were determined according to EN 12350-2, 5, 6 and 7.5,16-18

Although some of the methods are intended primarily for air-entrained concrete (2.2 and 2.3), it should be noted that, in terms of the entrained-air-void content, even non-entrained concretes contain voids corresponding, in size, to the entrained-air pores in air-entrained concrete.

Table 1: Composition of individual mixtures

Tabela 1: Sestava posameznih mešanic

\begin{tabular}{|c|c|c|c|c|c|c|}
\hline \multirow[b]{2}{*}{$\begin{array}{l}\text { Com- } \\
\text { ponent }\end{array}$} & \multicolumn{3}{|c|}{ Aggregates (kg) } & \multirow{2}{*}{$\begin{array}{c}\text { Cement } \\
42,5 \mathrm{R}, \\
\text { Mokrá } \\
(\mathrm{kg})\end{array}$} & \multirow[b]{2}{*}{$\begin{array}{l}\text { Water } \\
(\mathrm{kg})\end{array}$} & \multirow[b]{2}{*}{$\begin{array}{c}\text { Water } \\
\text { ratio } \\
(-)\end{array}$} \\
\hline & $\mid \begin{array}{c}0-4 \\
\text { Bratčice }\end{array}$ & $\begin{array}{c}4-8 \\
\text { Olbra- } \\
\text { movice }\end{array}$ & $\begin{array}{l}8-16 \\
\text { Olbra- } \\
\text { movice }\end{array}$ & & & \\
\hline \multicolumn{7}{|c|}{ Concrete mixture R - C12/15 X0 S3 D16 } \\
\hline & 978 & 177 & 693 & 255 & 206 & 0.81 \\
\hline \multicolumn{7}{|c|}{ Concrete mixture 0/1 - C20/25 X0 S3 D16 } \\
\hline & 927 & 182 & 698 & 309 & 202 & 0.65 \\
\hline \multicolumn{7}{|c|}{ Concrete mixture 0/2 - C30/37 X0 S3 D16 } \\
\hline & 892 & 175 & 695 & 358 & 192 & 0.54 \\
\hline \multicolumn{7}{|c|}{ Concrete mixture 0/3 - C35/45 (45/55) X0 S3 D16 } \\
\hline & 888 & 202 & 692 & 402 & 203 & 0.50 \\
\hline
\end{tabular}

Table 2: Characteristics of fresh concrete for individual mixtures Tabela 2: Značilnosti svežega betona posameznih mešanic

\begin{tabular}{|c|c|c|c|c|}
\hline & \multicolumn{4}{|c|}{ Characteristics } \\
\hline Concrete & $\begin{array}{c}\text { Flow table } \\
\text { test } \\
(\mathrm{mm})\end{array}$ & $\begin{array}{c}\text { Density of } \\
\text { fresh con- } \\
\text { crete } \\
\left(\mathrm{kg} / \mathrm{m}^{3}\right)\end{array}$ & $\begin{array}{c}\text { Total air } \\
\text { content }(\%) \\
\text { (pressure } \\
\text { method) }\end{array}$ & $\begin{array}{c}\text { Micro air } \\
\text { content } A_{300} \\
(\%) \\
(\mathrm{AVA})\end{array}$ \\
\hline$R$ & 435 & 2250 & 2.7 & 0.2 \\
\hline $0 / 1$ & 410 & 2315 & 2.7 & 0.1 \\
\hline $0 / 2$ & 385 & 2315 & 2.5 & 0.0 \\
\hline $0 / 3$ & 420 & 2290 & 2.5 & 0.1 \\
\hline
\end{tabular}

For method 2.1, the specimen volume was $8 \mathrm{dm}^{3}$. This method enables a detection of pores $>300 \mu \mathrm{m}$. It is the most commonly used method; however, its disadvantage is that it only allows a determination of the total air content and gives no information the on pore distribution and size.

In the case of method 2.2, the specimen volume was approximately $50 \mathrm{~cm}^{3}$. As it was a relatively small specimen, obtained with an impact drill, it was highly probable that it contained only smaller-sized pores $(<2 \mathrm{~mm})$.

For the procedure according to 2.3 , the specimen was a concrete slab of $100 \mathrm{~mm} \times 100 \mathrm{~mm}$. The evaluation was performed in two ways, i.e., manually and automatically, both of which have their drawbacks, see 2.3. Automatic evaluation took place at a resolution of $1 \mu \mathrm{m}$ 


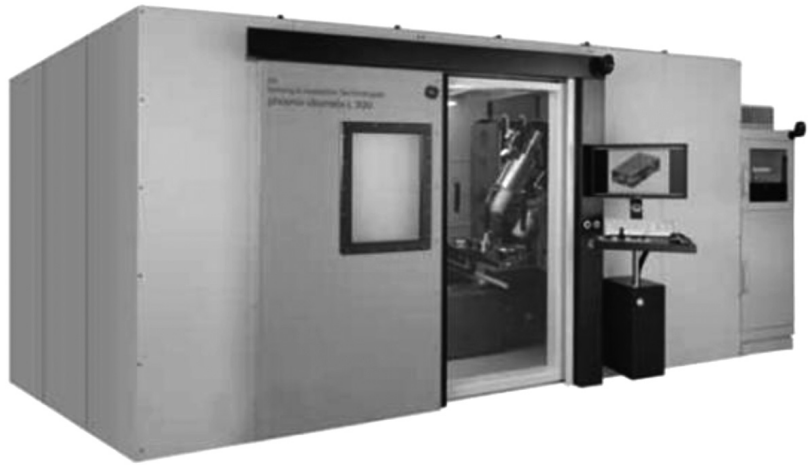

Figure 4: Phoenix v|tome|x L $240^{19}$

Slika 4: Naprava Phoenix v|tome|x L $240^{19}$

per pixel, which corresponds to the minimum size of a detectable pore.

For the measurement with method 2.4 , cylindrical specimens of $50 \mathrm{~mm}$ in diameter and $60 \mathrm{~mm}$ in height were used. All the cylinders were obtained from larger specimens, using a core drill. The drilling was performed perpendicular to the surface of the concrete and each specimen was cut to a length of $60 \mathrm{~mm}$ in order to represent the concrete cover. At this specimen size, the device was able to detect the pores of above $100 \mu \mathrm{m}$.

Each cylinder was scanned in consecutive slices using device Phoenix v|tome|x L 240 (Figure 4). ${ }^{19}$ All the data was recorded and subsequently processed in the laboratory of the Central European Institute of Technology - Brno University of Technology (CEITEC BUT). A module of VG Studio MAX was used for the pore analysis. $^{20}$

Table 3: Characteristics of air voids for concrete $R$ Tabela 3: Značilnosti zračnih por v betonu $R$

\begin{tabular}{|c|c|c|c|c|c|}
\hline & \multicolumn{5}{|c|}{ Used methods } \\
\hline & \multicolumn{2}{|c|}{ Fresh concrete } & \multicolumn{3}{|c|}{ Hardened concrete } \\
\hline & \multirow{2}{*}{$\begin{array}{l}\text { Pressure } \\
\text { method }\end{array}$} & \multirow{2}{*}{$\begin{array}{l}\text { Air-void } \\
\text { analyser }\end{array}$} & \multicolumn{2}{|c|}{$\begin{array}{l}\text { Microscopy analysis } \\
\text { spacing }\end{array}$} & \multirow{2}{*}{$\begin{array}{c}\text { Computer } \\
\text { tomo- } \\
\text { graphy }\end{array}$} \\
\hline & & & manual & automatic & \\
\hline \multirow{2}{*}{$\begin{array}{c}\text { Total air } \\
\text { content } A \\
(\%) \\
\end{array}$} & \multirow{2}{*}{2.7} & $\bar{x}=1.1$ & $\bar{x}=2.86$ & $\bar{x}=10.72$ & \multirow{2}{*}{1.69} \\
\hline & & $s=0.3$ & $s=0.21$ & $s=0.49$ & \\
\hline \multirow{2}{*}{\begin{tabular}{|c|} 
Micro air \\
content \\
$A_{300}(\%)$ \\
\end{tabular}} & \multirow{2}{*}{-} & $\bar{x}=0.15$ & $\bar{x}=1.20$ & $\bar{x}=5.58$ & \multirow{2}{*}{0.05} \\
\hline & & $s=0.05$ & $s=0.11$ & $s=0.67$ & \\
\hline \multirow{2}{*}{\begin{tabular}{|c|} 
Spacing \\
factor $L$ \\
$(\mathrm{~mm})$ \\
\end{tabular}} & \multirow{2}{*}{-} & \multirow{2}{*}{1.13} & $\bar{x}=0.11$ & $\bar{x}=0.08$ & \multirow{2}{*}{0.70} \\
\hline & & & $s=0.00$ & $s=0.01$ & \\
\hline \multirow{2}{*}{\begin{tabular}{|c|}
$\begin{array}{c}\text { Average } \\
\text { pore } \\
\text { diameter } \\
D(\mu \mathrm{m})\end{array}$ \\
\end{tabular}} & \multirow{2}{*}{-} & \multirow{2}{*}{-} & \multirow{2}{*}{-} & $\bar{x}=114.50$ & \multirow{2}{*}{320.0} \\
\hline & & & & $s=6.50$ & \\
\hline \multirow{2}{*}{$\begin{array}{l}\text { Specific } \\
\text { surface of } \\
\text { air-void } \\
\text { system } \alpha \\
\left(\mathrm{mm}^{-1}\right)\end{array}$} & \multirow[b]{2}{*}{-} & \multirow[b]{2}{*}{7.5} & $\bar{x}=57.65$ & $\bar{x}=35.04$ & \multirow[b]{2}{*}{11.48} \\
\hline & & & $s=1.65$ & $s=1.95$ & \\
\hline
\end{tabular}

\section{RESULTS AND DISCUSSION}

Tables 3 to 6 show the air-pore characteristics obtained with the selected methods for fresh and hardened concrete. Figures 5 to 9 show the method outputs. In the cases, where the measurement was performed on more specimens, the tables include their average values and standard diversions. The number of decimal places in the tables is based on the output of individual methods.

Table 4: Characteristics of air voids for concrete $0 / 1$

Tabela 4: Značilnosti zračnih por v betonu $0 / 1$

\begin{tabular}{|c|c|c|c|c|c|}
\hline & \multicolumn{5}{|c|}{ Used methods } \\
\hline & \multicolumn{2}{|c|}{ Fresh concrete } & \multicolumn{3}{|c|}{ Hardened concrete } \\
\hline & \multirow{2}{*}{$\begin{array}{l}\text { Pressure } \\
\text { method }\end{array}$} & \multirow{2}{*}{$\begin{array}{l}\text { Air-void } \\
\text { analyser }\end{array}$} & \multicolumn{2}{|c|}{$\begin{array}{c}\text { Microscopy analysis } \\
\text { spacing }\end{array}$} & \multirow{2}{*}{$\begin{array}{c}\text { Computer } \\
\text { tomo- } \\
\text { graphy }\end{array}$} \\
\hline & & & manual & automatic & \\
\hline \multirow{2}{*}{$\begin{array}{c}\text { Total air } \\
\text { content } A \\
(\%)\end{array}$} & \multirow{2}{*}{2.7} & \multirow{2}{*}{0.9} & \multirow{2}{*}{1.48} & $\bar{x}=4.44$ & \multirow{2}{*}{1.85} \\
\hline & & & & $\mathrm{s}=0.15$ & \\
\hline \multirow{2}{*}{$\begin{array}{c}\text { Micro air } \\
\text { content } \\
A_{300}(\%)\end{array}$} & \multirow{2}{*}{-} & \multirow{2}{*}{0.0} & \multirow{2}{*}{0.27} & $\bar{x}=1.93$ & \multirow{2}{*}{0.02} \\
\hline & & & & $\mathrm{s}=0.01$ & \\
\hline \multirow{2}{*}{$\begin{array}{l}\text { Spacing } \\
\text { factor } L \\
(\mathrm{~mm})\end{array}$} & \multirow{2}{*}{-} & \multirow{2}{*}{1.80} & \multirow{2}{*}{0.27} & $\bar{x}=0.13$ & \multirow{2}{*}{1.01} \\
\hline & & & & $\mathrm{s}=0.01$ & \\
\hline \multirow{2}{*}{$\begin{array}{l}\text { Average } \\
\text { pore } \\
\text { diameter } \\
D(\mu \mathrm{m})\end{array}$} & \multirow[b]{2}{*}{-} & \multirow[b]{2}{*}{-} & \multirow[b]{2}{*}{-} & $\bar{x}=99.00$ & \multirow[b]{2}{*}{416.0} \\
\hline & & & & $\mathrm{s}=12.00$ & \\
\hline \multirow{2}{*}{\begin{tabular}{|c|} 
Specific \\
surface of \\
air-void \\
system $\alpha$ \\
$\left(\mathrm{mm}^{-1}\right)$
\end{tabular}} & \multirow[b]{2}{*}{-} & \multirow[b]{2}{*}{6.0} & \multirow[b]{2}{*}{31.80} & $\bar{x}=41.06$ & \multirow[b]{2}{*}{7.82} \\
\hline & & & & $\mathrm{s}=5.13$ & \\
\hline
\end{tabular}

Table 5: Characteristics of air voids for concrete $0 / 2$

Tabela 5: Značilnosti zračnih por v betonu $0 / 2$

\begin{tabular}{|c|c|c|c|c|c|}
\hline & \multicolumn{5}{|c|}{ Used methods } \\
\hline & \multicolumn{2}{|c|}{ Fresh concrete } & \multicolumn{3}{|c|}{ Hardened concrete } \\
\hline & \multirow{2}{*}{$\begin{array}{l}\text { Pressure } \\
\text { method }\end{array}$} & \multirow{2}{*}{$\begin{array}{l}\text { Air-void } \\
\text { analyser }\end{array}$} & \multicolumn{2}{|c|}{$\begin{array}{l}\text { Microscopy analysis } \\
\text { spacing }\end{array}$} & \multirow{2}{*}{$\begin{array}{c}\text { Computer } \\
\text { tomo- } \\
\text { graphy }\end{array}$} \\
\hline & & & manual & automatic & \\
\hline \multirow{2}{*}{$\begin{array}{c}\text { Total air } \\
\text { content } A \\
(\%)\end{array}$} & \multirow{2}{*}{2.5} & \multirow{2}{*}{1.0} & \multirow{2}{*}{1.76} & $\bar{x}=2.90$ & \multirow{2}{*}{1.95} \\
\hline & & & & $\mathrm{s}=0.33$ & \\
\hline \multirow{2}{*}{$\begin{array}{l}\text { Micro air } \\
\text { content } \\
A_{300}(\%)\end{array}$} & \multirow{2}{*}{-} & \multirow{2}{*}{0.1} & \multirow{2}{*}{0.39} & $\bar{x}=1.33$ & \multirow{2}{*}{0.01} \\
\hline & & & & $s=0.36$ & \\
\hline \multirow{2}{*}{$\begin{array}{l}\text { Spacing } \\
\text { factor } L \\
(\mathrm{~mm})\end{array}$} & \multirow{2}{*}{-} & \multirow{2}{*}{1.28} & \multirow{2}{*}{0.28} & $\bar{x}=0.14$ & \multirow{2}{*}{1.16} \\
\hline & & & & $\mathrm{s}=0.04$ & \\
\hline \multirow{2}{*}{$\begin{array}{c}\text { Average } \\
\text { pore } \\
\text { diameter } \\
D(\mu \mathrm{m})\end{array}$} & \multirow[b]{2}{*}{-} & \multirow[b]{2}{*}{-} & \multirow[b]{2}{*}{-} & $\bar{x}=86.50$ & \multirow[b]{2}{*}{406.0} \\
\hline & & & & $s=18.50$ & \\
\hline \multirow{2}{*}{\begin{tabular}{|} 
Specific \\
surface of \\
air-void \\
system $\alpha$ \\
$\left(\mathrm{mm}^{-1}\right)$
\end{tabular}} & \multirow[b]{2}{*}{-} & \multirow[b]{2}{*}{8.1} & \multirow[b]{2}{*}{29.1} & $\bar{x}=48.68$ & \multirow[b]{2}{*}{6.68} \\
\hline & & & & $\mathrm{s}=10.47$ & \\
\hline
\end{tabular}


Table 6: Characteristics of air voids for concrete $0 / 3$ Tabela 6: Značilnosti zračnih por v betonu $0 / 3$

\begin{tabular}{|c|c|c|c|c|c|}
\hline & \multicolumn{5}{|c|}{ Used methods } \\
\hline & \multicolumn{2}{|c|}{ Fresh concrete } & \multicolumn{3}{|c|}{ Hardened concrete } \\
\hline & \multirow{2}{*}{$\begin{array}{l}\text { Pressure } \\
\text { method }\end{array}$} & \multirow{2}{*}{$\begin{array}{l}\text { Air-void } \\
\text { analyser }\end{array}$} & \multicolumn{2}{|c|}{$\begin{array}{c}\text { Microscopy analysis } \\
\text { spacing }\end{array}$} & \multirow{2}{*}{$\begin{array}{c}\text { Computes } \\
\text { tomo- } \\
\text { graphy }\end{array}$} \\
\hline & & & manual & automatic & \\
\hline \multirow{2}{*}{$\begin{array}{c}\text { Total air } \\
\text { content } A \\
(\%)\end{array}$} & \multirow{2}{*}{2.5} & \multirow{2}{*}{1.0} & \multirow{2}{*}{2.48} & $\bar{x}=3.51$ & \multirow{2}{*}{1.70} \\
\hline & & & & $\mathrm{s}=0.78$ & \\
\hline \multirow{2}{*}{$\begin{array}{l}\text { Micro air } \\
\text { content } \\
A_{300}(\%)\end{array}$} & \multirow{2}{*}{-} & \multirow{2}{*}{0.1} & \multirow{2}{*}{0.26} & $\bar{x}=1.69$ & \multirow{2}{*}{0.01} \\
\hline & & & & $\mathrm{s}=0.44$ & \\
\hline \multirow{2}{*}{$\begin{array}{l}\text { Spacing } \\
\text { factor } L \\
(\mathrm{~mm})\end{array}$} & \multirow{2}{*}{-} & \multirow{2}{*}{1.26} & \multirow{2}{*}{0.40} & $\bar{x}=0.13$ & \multirow{2}{*}{0.93} \\
\hline & & & & $\mathrm{s}=0.03$ & \\
\hline \multirow{2}{*}{$\begin{array}{c}\text { Average } \\
\text { pore } \\
\text { diameter } \\
D(\mu \mathrm{m})\end{array}$} & \multirow{2}{*}{-} & \multirow{2}{*}{-} & \multirow{2}{*}{-} & $\bar{x}=88.5$ & \multirow{2}{*}{445.0} \\
\hline & & & & $s=10.5$ & \\
\hline \multirow{2}{*}{$\begin{array}{l}\text { Specific } \\
\text { surface of } \\
\text { air-void } \\
\text { system } \alpha \\
\left(\mathrm{mm}^{-1}\right)\end{array}$} & \multirow[b]{2}{*}{-} & \multirow{2}{*}{8.4} & \multirow{2}{*}{18.20} & $\bar{x}=45.8$ & \multirow{2}{*}{9.20} \\
\hline & & & & $s=5.45$ & \\
\hline
\end{tabular}

When determining the total air content in fresh concrete, the AVA method gave lower values than the pressure method (Figure 5), which could have been caused by the amount of fresh concrete being tested.

Different values of manual and automatic microscopy may have been caused by the ability/inability to distinguish between an air pore and a hollow created by a particle of the aggregate forced out during the cutting or grinding of the specimen. The differences may have also been caused by the operator during the manual measurement of the factor. During automatic measurement, the

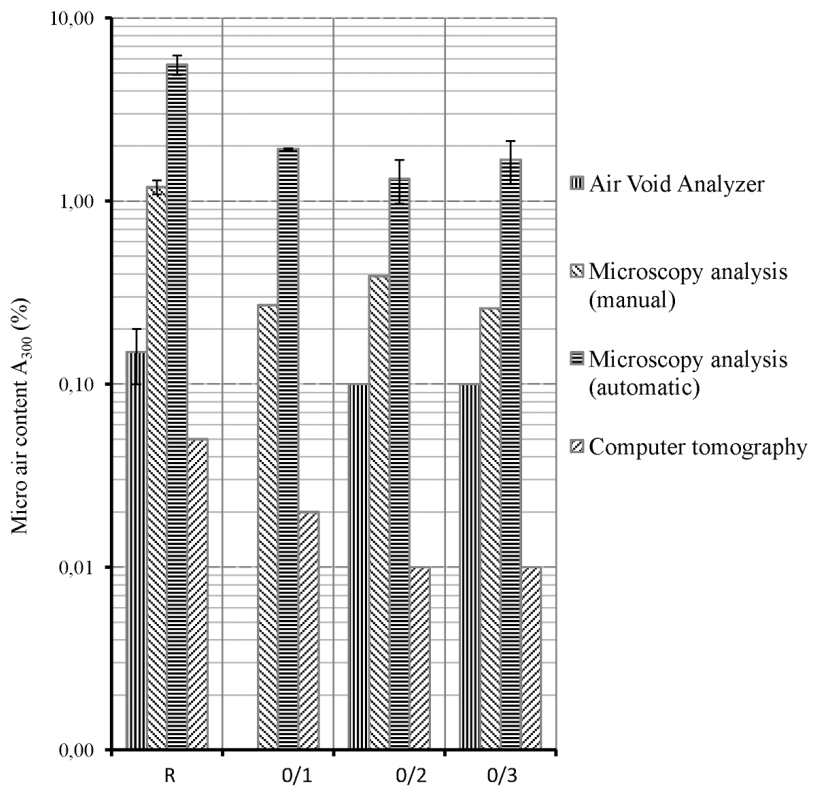

Figure 6: Results of micro-air-void content $A_{300}$ for individual concretes

Slika 6: Rezultati vsebnosti zraka v mikroporah $A_{300}$ pri posemeznih betonih

ability to detect a pore depends on the resolution (in our case, $1 \mu \mathrm{m}$ per pixel), while during manual measurement, this ability lies with the technician performing the test.

Figure 6 shows that out of all the methods used, the measurement results obtained with CT and AVA corresponded most closely to each other. A small difference between these results was probably caused by different abilities to detect air voids at the bottom threshold of the detection: AVA (at $50 \mu \mathrm{m}$ ), CT (at $100 \mu \mathrm{m}$ ).

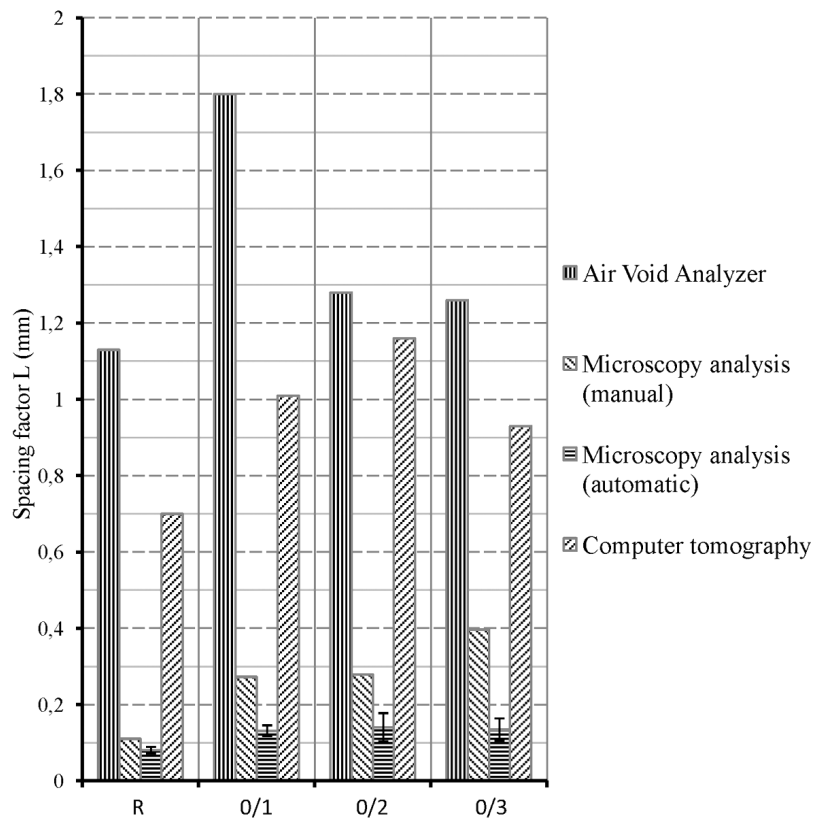

Figure 7: Results of spacing factor for individual concretes Slika 7: Rezultati faktorja ločljivosti pri posameznih betonih
Figure 5: Results of total air content for individual concretes Slika 5: Rezultati vsebnosti vsega zraka v posameznem betonu

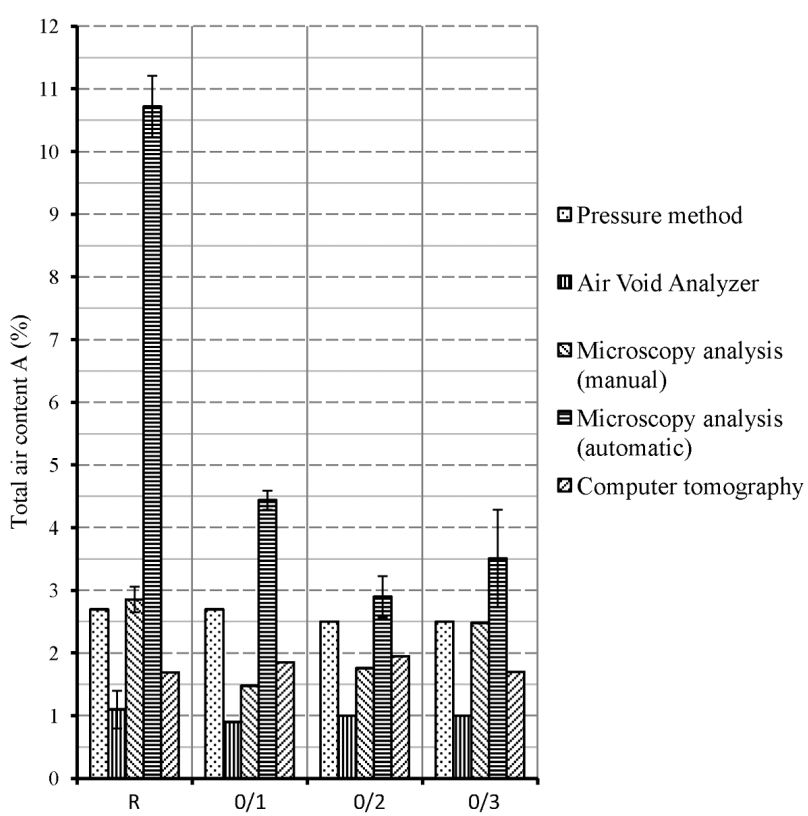

Materiali in tehnologije / Materials and technology 50 (2016) 4, 491-498 


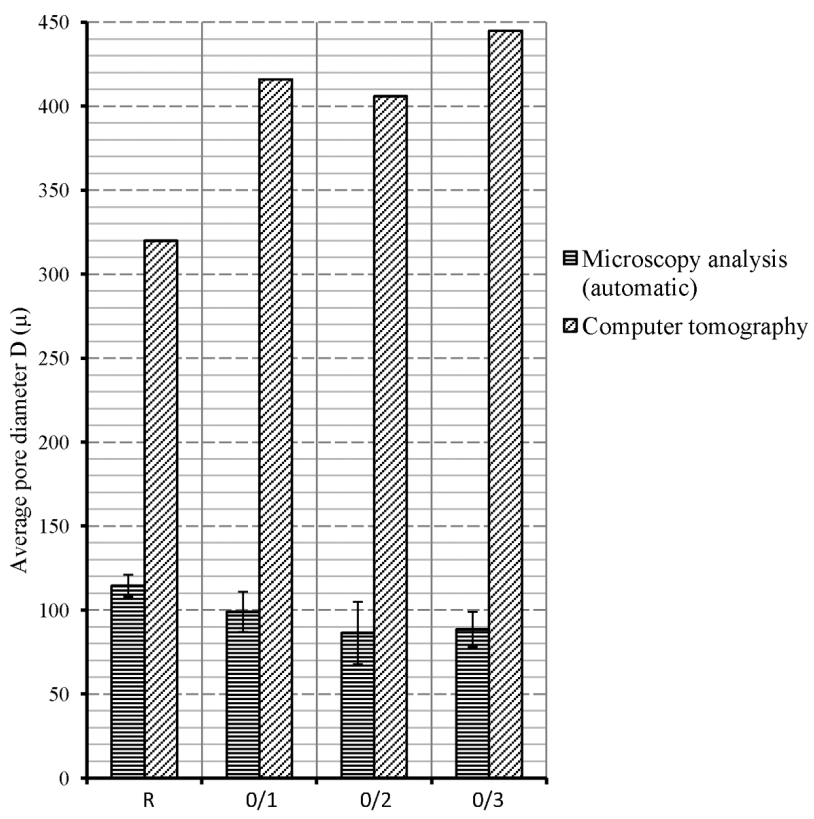

Figure 8: Results of average pore diameter for individual concretes Slika 8: Rezultati povprečne velikosti por pri posameznih betonih

In general terms, it can be stated that, in determining the $A_{300}$ value, a comparison of the results of individual methods was very demanding. All the methods exhibited a trend of a decrease in the resulting values of $A_{300}$ dependent on the increasing cement content in the individual concretes; however, each method displayed significantly different absolute values of $A_{300}$.

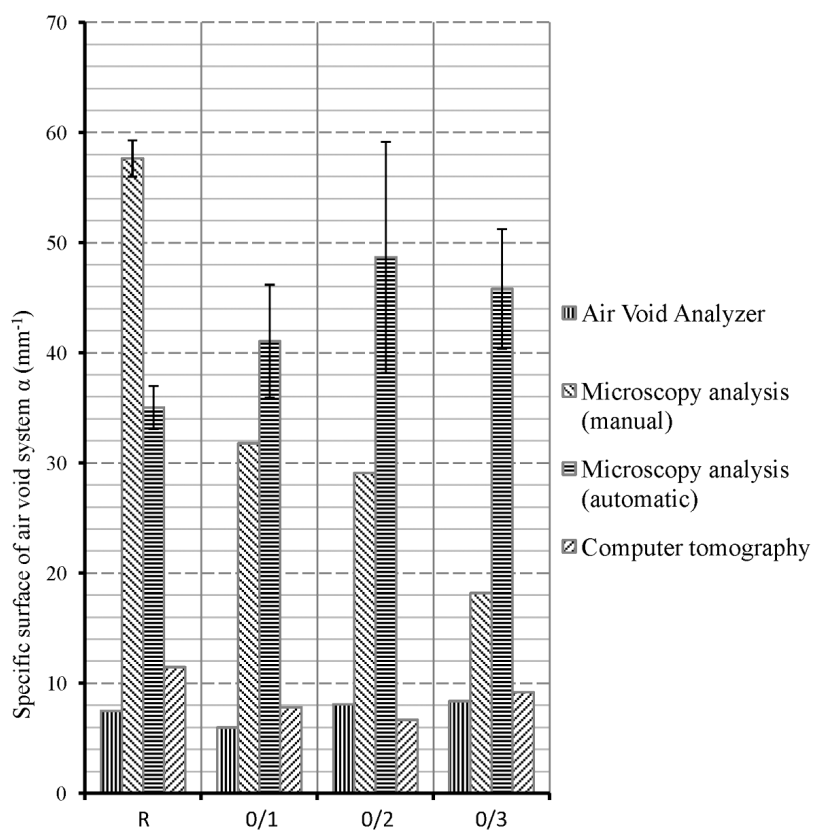

Figure 9: Results of specific surface of air-void system for individual concretes

Slika 9: Rezultati specifične površine sistema zračnih por pri posameznih betonih

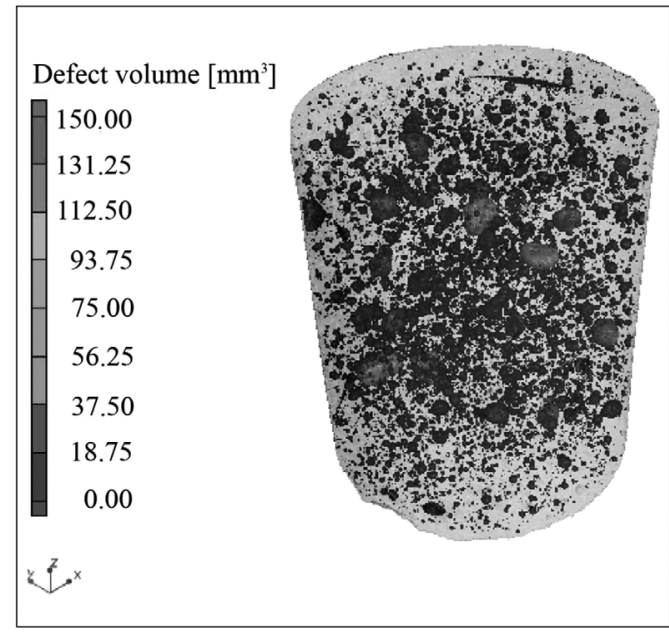

Figure 10: Volume of air-void system - 3D

Slika 10: Volumen sistema zračnih por - 3D

Based on the results shown in Figure 7, it could be stated that a comparison of the outcomes of the methods was again very demanding. The results that at least partially corresponded to each other were the values from the measurement using manual and automatic microscopy.

No conclusive proof was found for the premise that the spacing-factor results obtained with $\mathrm{CT}$ and the microscope would differ only minimally. This fact may have been caused by a difference in the mathematical model of the calculation between the microscope and $\mathrm{CT}$. In the case of the microscope, the spacing factor was calculated from 2D scanning of the specimen, while in the case of CT, it was calculated from 3D scanning.

All the used methods displayed significantly different values of the average pore size for different concretes, as shown in Figure 8. The cause of the higher values in case of CT was probably its measurement range, where the bottom threshold was defined at $100 \mu \mathrm{m}$ and the top threshold was not defined in this experiment; therefore,

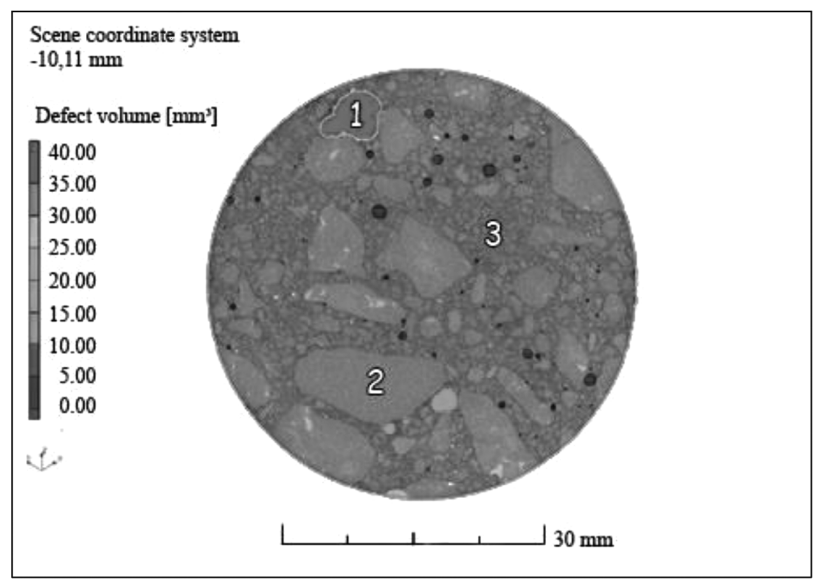

Figure 11: Volume of air-void system - cross-section: 1 - air void, 2 aggregate particle, 3 - cement paste

Slika 11: Volumen sistema zračnih por - presek: 1-zračna pora, 2 delec agregata, 3 - cementna osnova 
possible air voids may have also been included in the calculation. On the other hand, the microscope had its range limited to the maximum pore diameter of 4000 $\mu \mathrm{m}$.

The measurements using CT and AVA displayed lower final values of the specific surface of the air-void system, while the results obtained with microscopy were significantly higher. It was nearly impossible to find any correlation between these results (Figure 9).

A possible cause for this great difference in the results may have been, much like in the case of most of the other properties, a different range of the diameter of the air pores being measured with the above methods and, in the case of CT, also the detection of possible air voids.

Some outcomes of the measurement with CT (the pore distribution and volume) are shown in Figures 10 and $\mathbf{1 1 .}$

\section{CONCLUSION}

The performed measurements allowed the following conclusions:

- The results of the used methods are difficult to compare. The main causes for this difficulty are probably different air-pore measurement ranges and the measurement of different types of pores (Figure 1). The characteristics determined with the individual methods performed on the concretes hardly correspond to one another. If one method indicates a certain trend in the results based on the cement content in the concrete, the other methods do not generally follow the trend or they even contradict it.

- A conclusive comparison of the results of the methods for determining the air content in concrete would require us to include, in the calculation, only the pore diameters within the intersection of the measurement ranges of the all the methods used (Figure 1).

- When measuring according to EN 480-11, differences are found in the results for the pores recorded manually and automatically. Possible causes are the inability of automatic recording to differentiate between an air pore and a missing particle of the aggregate and different abilities of detecting a pore at the bottom resolution threshold during each method of evaluation.

- AVA and stereoscopic microscope are primarily intended for determining the pore characteristics of aerated concretes. Based on the obtained results, it can be concluded that these methods probably give lower predictive values when used for non-aerated concretes.

- CT is a modern method for determining the concrete porosity with a great potential lying in the possibility of rendering the complete pore structure of a concrete specimen in 3D. Given the fact that it is demanding to set up the device along with the evaluation software, it appears that a correct interpretation of results is rather difficult. The results include possible voids, which would have to be filtered out of the chosen algorithm, thus increasing the accuracy of the predictive values.

- The results of this experiment may have been influenced by the small number of the specimens used, e.g., in the case of CT, each type of concrete was represented by one specimen only.

- CT appears to be a very suitable method for measuring air-pore characteristics in concrete; it is, however, necessary to tackle the above-mentioned flaws (filtering possible voids, a correct set-up of the device). When these problems are removed, the outputs of CT can be used as a benchmark for the results of the other methods measuring the pore structure in concrete, mainly thanks to detailed 3D mapping.

- During the determination of concrete-pore characteristics, it is necessary to consider the types and sizes of the pores being examined, which are the key factors for the purpose and characteristics of a pore system. It is then possible to choose the most suitable method of their determination in line with Figure 1.

\section{Acknowledgement}

This paper was elaborated with the financial support of the Czech Science Foundation, project GA13-18870S, and Junior Specific Research FAST-J-15-2703.

\section{REFERENCES}

${ }^{1}$ Regulation (EU) No 305/2011 of the European parliament and of the council of 9 March 2011 laying down harmonised conditions for the marketing of construction products and repealing Council Directive 89/106/EEC, http://eur-lex.europa.eu/legal-content/EN/TXT/?uri= celex:32011R0305

${ }^{2}$ B. Kucharczyková, P. Misák, T. Vymazal, Determination and evaluation of the air permeability coefficient using Torrent Permeability Tester, Russian Journal of Nondestructive Testing, 46 (2010) 3, 226-233, doi:10.1134/S1061830910030113

${ }^{3}$ M. Golová, Relationship between the basic properties of aerated concrete and its resistance to influence of environment, Diploma Thesis, Technical University of Ostrava, Ostrava 2012

${ }^{4}$ F. Collins, J. G. Sanjayan, Effect of pore size distribution on drying shrinking of alkali-activated slag concrete, Cement and Concrete Research, 30 (2000) 9, 1401-1406, doi:10.1016/S0008-8846(00) 00327-6

${ }^{5}$ EN 12350-7 Testing fresh concrete - Part 7: Air content - Pressure methods, ÚNMZ, 2009

${ }^{6}$ Apparatus for analysis of air pore structure: Quality Guarantee of air pores in concrete, http://www.avas-concrete.com, 23.07.2015

${ }^{7}$ J. Distlehorst, G. Kurgan, Development of Precision Statement for Determining Air Void Characteristics of Fresh Concrete with Use of Air Void Analyzer, Transportation Research Record: Journal of the Transportation Research Board, 2020 (2007), 45-49, doi:10.3141/ 2020-06

${ }^{8}$ AVA - Air Void Analyzer, http://www.germann.org/, 18.08.2015 
B. MORAVCOVÁ et al.: POSSIBILITIES OF DETERMINING THE AIR-PORE CONTENT IN CEMENT COMPOSITES ...

${ }^{9}$ EN 480-11, Admixtures for concrete, mortar and grout - Test methods - Part 11: Determination of air void characteristics in hardened concrete, ÚNMZ, 2005

${ }^{10}$ J. Kaiser, M. Holá, M. Galiová, K. Novotný, V. Kanický, P. Martinec, J. Ščučka, F. Brun, N. Sodini et al., Investigation of the microstructure and mineralogical composition of urinary calculi fragments by synchrotron radiation X-ray microtomography: a feasibility study, Urological Research, 39 (2011) 4, 259-267, doi:10.1007/s00240-010-0343-9

${ }^{11}$ EN 206 Concrete - Specification, performance, production and conformity, ÚNMZ, 2013

${ }^{12}$ EN 196-6 Methods of testing cement - Part 6: Determination of fineness, ÚNMZ, 2010

${ }^{13}$ EN 933 Tests for geometrical properties of aggregates, ÚNMZ, 2012
${ }^{14}$ EN 1097 Tests for mechanical and physical properties of aggregates, ÚNMZ, 2011

${ }^{15}$ EN 12350-1 Testing fresh concrete - Part 1: Sampling, ÚNMZ, 2009

${ }^{16}$ EN 12350-2 Testing fresh concrete - Part 2: Slump test, ÚNMZ, 2009

${ }^{17}$ EN 12350-5 Testing fresh concrete - Part 5: Flow table test, ÚNMZ, 2009

${ }^{18}$ EN 12350-6 Testing fresh concrete - Part 6: Density, ÚNMZ, 2009

${ }^{19}$ V|tome|x L 240 Brochure, GE Measurement \& Control, 2014, http://www.ge-mcs.com/download/x-ray/phoenix-X-ray/GEIT_ 31205_flyer_vtomex_L_EN_1213.pdf, 23.7.2015

${ }^{20} \mathrm{VG}$ studio MAX software, http://www.volumegraphics.com/en/ products/vgstudio-max 